\title{
Antigenic Relationship between Puerto Rican Pepper- Mosaic Virus and a Strain of Potato Virus Y
}

\author{
$J$. Enrique Pérez and $J$. Adsuar ${ }^{1}$ \\ INTRODUCTION
}

Puerto Rican pepper-mosaic virus, studied in some detail by Roque and Adsuar $(1)^{2}$ was reported by these authors as having properties similar to the potato vein-banding virus. Viruses producing the "mottle" or mosaic symptoms in pepper and tobacco plants $(2,3,4)$ have been related at one time or another to viruses producing diseases in the potato, particularly the " $\mathrm{Y}$ " group of viruses. Cross-resistance tests involving the potato vein-banding virus, potato virus $\mathrm{Y}$, and the Puerto Rican pepper-mosaic virus have shown a relationship between the two infectious agents. ${ }^{3} \mathrm{It}$ therefore seemed of interest to confirm the relation between potato virus $\mathrm{Y}$ and the Puerto Rican virus by means of precipitin tests.

\section{EXPERIMENTAL PROCEDURE}

A typical strain of potato virus $\mathrm{Y}^{4}$ and the Puerto Rican pepper mosaic virus (P.R.P.M.) were propagated on young tobacco plants, variety Virginia 12. Leaves showing good symptoms were harvested 2 to 3 weeks after inoculation, washed in sterile tapwater, ground in mortars, and the sap expressed by wringing the macerate through two layers of cheesecloth. The sap was then clarified by low-speed centrifugation for 20 to 30 minutes. Each virus was injected separately by the intraperitoneal route into two rabbits. Five-milliliter doses of infective clarified sap were given at 3- to 4-day intervals as immunizing antigen. A total of eight injections was given to each rabbit using always freshly expressed sap. Throughout the immunization period blood samples were taken to ascertain the antibody response.

The precipitation test was employed for determining the antibody response and the relationship between the viruses. The injection of the antigens produced antisera that precipitated with clarified sap from tobacco plants inoculated with both the potato $\mathrm{Y}$ virus strain and the P.R.P.M. virus.

The sera were first absorbed with normal tobacco sap and then titrated

${ }^{1}$ Associate Bacteriologist and Phytopathologist, respectively, Agricultural Experiment Station, University of Puerto Rico, Río Piedras, P. R.

${ }^{2}$ Numbers in parentheses refer to Literature Cited, p. 167.

${ }^{3}$ Unpublished data, J. Adsuar.

${ }^{4} \mathrm{We}$ are indebted to A. Frank Ross, College of Agriculture, Cornell University, for supplying this strain. 
against both homologous and heterologous antigens. In the tests, dilutions of serum made in 0.85-percent saline solution were mixed with an equal volume of clarified infective sap. The mixtures were shaken and incubated at $37^{\circ} \mathrm{C}$. for 2 hours. Readings were made at 1 and 2 hours after incubation.

Cross-absorption tests were carried out to determine whether specific antigenic groupings could be detected in each virus. The absorption tech-

TABLE 1.- Titer of antisera with homologous and heterologous antigen

\begin{tabular}{|c|c|c|}
\hline \multirow{2}{*}{ Serum } & \multicolumn{2}{|c|}{ Titer with antigen- } \\
\hline & P.R.P.M. & $\mathrm{Y}$ \\
\hline $\mathrm{Y} 890^{1} \ldots \ldots$ & $1 / 320$ & $1 / 640$ \\
\hline Y $982 \ldots \ldots \ldots \ldots$ & $1 / 320$ & $1 / 320$ \\
\hline P.R.P.M. $929^{2} \ldots \ldots \ldots \ldots \ldots \ldots$ & $1 / 1280$ & $1 / 1280$ \\
\hline P.R.P.M. $971 \ldots \ldots \ldots \ldots \ldots$ & $1 / 320$ & $1 / 160$ \\
\hline
\end{tabular}

$1 \mathrm{Y}$ antisera.

2 P.R.P.M. antisera.

TABLE 2.-Cross-absorption of antisera to P.R.P.M. and $Y$ antigens

\begin{tabular}{|c|c|c|c|}
\hline \multirow{2}{*}{ Serum } & \multirow{2}{*}{$\begin{array}{c}\text { Titer with homologous } \\
\text { antigen }\end{array}$} & \multicolumn{2}{|c|}{ Titer after absorption with- } \\
\hline & & $\mathrm{Y}$ antigen & P.R.R.M. antigen ${ }^{3}$ \\
\hline Y $890^{1}$. & $1 / 640$ & 0 & 0 \\
\hline $\mathrm{Y} 982 \ldots \ldots \ldots \ldots$ & $1 / 320$ & 0 & 0 \\
\hline P.R.P.M. $929^{2} \ldots \ldots \ldots \ldots \ldots$ & $1 / 1280$ & $1 / 20$ & 0 \\
\hline P.R.P.M. $971 \ldots \ldots \ldots \ldots \ldots$ & $1 / 320$ & 0 & 0 \\
\hline
\end{tabular}

${ }^{1}$ Antisera prepared with $\mathrm{Y}$ antigen.

${ }^{2}$ Antisera prepared with P.R.P.M. antigen.

${ }^{3}$ Lowest dilution of serum tested was $1 / 20$ (final dilution).

nique was as follows: 1 part of undiluted serum was mixed with 9 parts of either homologous or heterologous antigen (infective, clarified sap). The mixtures were incubated for 2 hours at $37^{\circ} \mathrm{C}$. and placed in the refrigerator until the following day. The precipitate formed was removed by centrifugation. The absorbed sera were then titrated against the homologous and the heterologous antigens.

\section{RESULTS}

As can be seen from table 1 the sera reacted almost as strongly with the . homologous as with the heterologous antigen. This alone proves that the potato $\mathrm{Y}$ and P.R.P.M. viruses are closely related strains. In table 2 the 
cross-absorption tests show that the P.R.P.M. antigen removed all antibodies to the $\mathrm{Y}$ antigen from the $\mathrm{Y}$ antisera. However when P.R.P.M. antiserum 929 was absorbed with $\mathrm{Y}$ antigen it still retained some precipitating power for the P.R.P.M. antigen, reacting at a dilution of $1 / 20$ (final dilution). This indicates the presence of a minor antigen in P.R.P.M. virus, which is absent from the Y virus. P.R.P.M. antiserum 971 did not react in the same way as 929 , but this may be explained on the basis of its titer being fourfold lower than that of 929 . It is well known that weak and strong sera behave differently both qualitatively and quantitatively (5).

\section{SUMMARY}

Antisera were prepared against the Puerto Rican pepper-mosaic virus (P.R.P.M.) and a typical strain of potato virus $\mathrm{Y}$ by inoculating rabbits with clarified sap from tobacco plants infected separately with each virus. All the four sera thus prepared reacted with both antigens. Cross-absorption tests showed that the P.R.P.M. virus possessed a minor antigenic component not found in the $\mathrm{Y}$ virus.

\section{RESUMEN}

Se prepararon antisueros para el virus que produce el mosaico del pimiento en Puerto Rico (P.R.P.M.) y una cepa tipo del virus $Y$ que ataca la papa, inoculando conejos con el jugo clarificado de plantas de tabaco infectadas separadamente con cada uno de estos virus. Todos los cuatro sueros, así preparados, reaccionaron con ambos antígenos. Pruebas cruzadas de absorción demostraron que el virus P.R.P.M. posee componentes antigénicos que no se encuentran en el virus $\mathrm{Y}$.

\section{IITERATURE CITED}

1. Roque, A., and Adsuar, J., Studies on the mosaic of peppers (Capsicum frutescens) in Puerto Rico, J. Agr. Univ. P. R., 25(4) 1-11, 1941.

2. Johnson, J., Transmission of viruses from apparently healthy potatoes, Wis. Agr. Exp. Sta. Bul. 63, 1925.

3. Blodgett, F. M., A potato virus on peppers; Phytopath. 17 775-82 1936.

4. Bald, J. G., and Norris, D. O., Virus C from an old Australian variety of potato, Phytopath. 35 591-7, 1945.

5. Kleczkowski, A., Quantitative studies on serological reactions of some plant viruses and of a pea nodule bacterium, Brit. J. Exp. Path. 22 44, 1941. 